\title{
Operation Planning Reservoir with Linear Programming Optimi- zation Model for Water Demand of the Community In Aceh Besar District
}

\author{
Wesli \\ Received: 27012015 / Accepted: 2402 2015 / Published online: 30062015 \\ (c) 2015 Faculty of Geography UGM and The Indonesian Geographers Association
}

\begin{abstract}
On the condition before building a dam, Aceh Besar district often a shortage of water for the needs of the community, so that people difficulty in doing their activities. There is a river in the Aceh Besar district named "Keuliling River". The river is one of the watershed sub-basins of Krueng Aceh which has large enough potential of water to increase the supply of raw water in order to meet the water needs of the Banda Aceh City and Aceh Besar district.Therefore, a reservoir building was built that able to acomodate a large capacity of water. The resorvoir was named "Keuliling Reservoir". "Reservoir Keuliling" has $38.20 \mathrm{~km} 2$ watershed areas, 259.94 hectares wide puddle on Normal Water Front (MAN), a total of 18,359,078 m3 bin normal water level at an elevation of $45.80 \mathrm{~m}$ and has an effective pitcher of 12.99,208 $\mathrm{m} 3$. The reservoir also serves as a provider of raw water for the development of inland fisheries, livestock, rice fields and others. The greatest needs are to be served by the reservoir is water requirement for paddy planting season Rendeng in October to December and the gadu growing season from April to June. To meet all these requirements then performed the planning operation of reservoir. Ie, by optimizing the volume of water storage at the end of the month through the optimization of the use of inflow data and outflow data. The optimization performed with optimization models Linear Programming. The results of the optimization is the volume of water in reservoirs that have large water needs, which in October is 13,380,986 m3, in November is 76,640,036 m3 and in December is 38,104,116 m3. Where in each month of the above conditions are still effective volume reservoirs at 12,992,080 m3. The results showed that from month to month never happened reservoir conditions at the level of the dead reservoirs, this illustrates that Keuliling reservoir can meet the water needs of the community.
\end{abstract}

Keywords: Reservoir operation, Debit, Reservoirs Volume, Linear Programming Optimization Model

Abstrak Kabupaten Aceh Besar pada kondisi sebelum dibangun waduk sering kali terjadi kekurangan air untuk kebutuhan masyarakat sehingga masyarakat kesulitan melakukan aktifitasnya.Pada Kabupaten Aceh Besar terdapat sungai Keuliling yang merupakan salah satu sub-basin Daerah Aliran Sungai Krueng Aceh yang mempunyai potensi air yang cukup besar untuk meningkatkan penyediaan air baku dalam rangka memenuhi kebutuhan air untuk kota Banda Aceh dan Aceh Besar. Maka untuk itu dibangun suatu bangunan yang dapat menampung kapasitas air dalam jumlah besar yaitu dengan membangun waduk Keuliling. Waduk Keuliling mempunyai Luas Daerah Aliran Sungai 38,20 km2, luas genangan pada Muka Air Normal (MAN) sebesar 259,94 ha, tampungan total muka air normal pada elevasi 45,80 m sebesar $18.359 .078 \mathrm{~m} 3$ dan tampungan efektif sebesar $12.992 .080 \mathrm{~m} 3$ serta berfungsi sebagai penyedia air baku untuk pengembangan perikanan darat, peternakan, persawahan dan lainnya. Kebutuhan yang yang paling besar adalah kebutuhan persawahan dengan musim tanam rendeng pada bulan Oktober sampai Desember dan musim tanam gadu pada bulan April sampai Juni.Untuk memenuhi semua kebutuhan dilakukan perencanaan pengoperasian waduk yaitu dengan mengoptimalkan volume tampungan air pada akhir bulan melalui optimasi penggunaan data debit inflow dan data debit outflow dapat dimaksimalkan. Optimasi dilakukan dengan model optimasi Linier Programming dan hasil yang diperoleh yaitu volume tampungan air pada bulan yang mempunyai kebutuhan air yang besar yaitu pada bulan Oktober adalah 13,380,986 m3, bulan November sebesar 76,640,036 m3 dan di bulan Desember sebesar 38,104,116 m3 di mana pada masing-masing bulan kondisinya masih di atas volume tampungan efektif (tampungan mati) sebesar $12.992 .080 \mathrm{m3}$. Hasil penelitian menunjukkan bahwa dari bulan ke bulan tidak pernah terjadi kondisi level waduk pada level tampungan mati, hal ini menggambarkan bahwa waduk Keuliling dapat memenuhi kebutuhan air masyarakat.

Kata kunci: Operasi Waduk, Debit, Volume tampungan, Model Optimasi Linear Programming

\section{Introduction}

On the condition before building a dam, Aceh Besar district often a shortage of water for the needs of the community, so that people difficulty in doing their activities. There is a river in the Aceh Besar district named

\section{Wesli}

Malikussaleh University Lhokseumawe, Indonesia

Email: ir_wesli@yahoo.co.id
"Keuliling River". The river is one of the watershed sub-basins of Krueng Aceh which has large enough potential of water to increase the supply of raw water in order to meet the water needs of the Banda Aceh City and Aceh Besar district. Therefore, a reservoir building was built that able to acomodate a large capacity of water. The reservoir was named "Keuliling Reservoir". 
Keuliling River is one of sub-watershed Krueng Aceh, which has the potential water considerable to supply raw water to fulfill needs of the Banda Aceh city and Aceh Besar District. Keuliling reservoir is located in the sub-district of Kuta Cot Glie within $\pm 35 \mathrm{~km}$ from the Banda Aceh city. Keuliling reservoir has an area of inundation at normal water level (MAN) 259.94 hectares, amount reservoirs of normal water surface elevation 18,359,078 $\mathrm{m} 3$ at $45.80 \mathrm{~m}$ level has an effective reservoir $12992.080 \mathrm{~m} 3$ and have a dead load for 4232943 $\mathrm{m} 3$ at $+37.50 \mathrm{~m}$ elevation. Primary water source is the Keuliling River with Watershed (DAS) area is 38.20 $\mathrm{km} 2$, lenght of river $12.3 \mathrm{~km}$ and width average is $\pm 7 \mathrm{~m}$.

This research effort for the management of water resources especially to optimize the utilization of available water distribution for various purposes mainly raw water and irrigation water where lack of water availability while increasing needs required for the determination of policy-setting discharge existing water distribution. In an effort to control the discharge of water distribution in this study using linear programming optimization model Srivastava [1992] argued that two types of optimization models are that linear programming and dynamic programming (continuous and discontinuous) were used for preliminary design purposes. The simulation technique was used for further screening. The linear programming model is most suitable for finding reservoir capacity. Linear Programming method was applied related to optimal operation of Kaskade reservoir which consisting of three reservoir in series to meet downstream water demand such as irrigation, municipal and industry. The case study used in the research is related to Kaskade reservoir system of Citarumriver (West Java) such as Saguling, Cirata and Jatiluhur reservoir. (Hadihardaja, 2006).

To obtain optimal results, the control is done by using simulated reservoir storage capacity performned, so the results will be closer to the empirical conditions. The aim of this study was to optimize the volume of water storage every month in the operation of the wa- ter distribution by using linear programming model. Benefit of the results of this study is one of the recommendations to the government in using the operating system of reservoirs.

\section{The Methods}

This study begins with a hydrologic analysis, which aims to determine the minimum flow of water as part of water availability. Hydrological analysis performed based on rainfall data and calculated into a rain plan to get rain intensity and flow.

According to Wesli [2008], rain plan in question is the maximum daily rainfall that will be used to calculate the intensity of rain then rain intensity is used to estimate the discharge plan. Rain plans can be calculated statistically based on data from previous rainfall.

Triatmodjo [2009] argued that, the determination of the type of distribution that fits the data performed by comparing the statistical parameters provided each type of distribution as shown in Table 1.

According Asdak [1995], the return period is the average time period that is expected to occur between two successive events. Return period ( $\mathrm{Tr}$ ) is usually predicted of the annual rainfall data series with the following equation: $\operatorname{Tr}=\frac{\mathrm{n}+1}{\mathrm{~m}}$

Where: $\operatorname{Tr}$ is the return period (years); $\mathrm{n}$ is the period of discharge data were recorded and $\mathrm{m}$ is the number of events, when compiled from the largest to the smallest.

To ensure that the rainfall data can be used in the analysis, it is necessary to test the suitability of the data distribution.

According to Wesli [2008], test the suitability of the Kolmogorov-Smirnov distribution is often also called the non-parametric test, because the test does not use a particular distribution function. Procedures the Kolmogorov-Smirnov test was conducted in the following:

Table 1. Statistical parameters to determine the type of distribution.

\begin{tabular}{|c|c|}
\hline Distribution & Requerement \\
\hline Normal & $\begin{array}{c}( \pm s)=68,27 \% \\
( \pm 2 s)=95,44 \% \\
C_{2}=0 \\
C_{2}=3\end{array}$ \\
\hline Log Normal & $\begin{array}{c}C_{,} \approx C_{v}^{3} \\
C_{k}=C_{\psi}^{3}+6 C_{k}^{t}+15 C_{y}^{+}+16\end{array}$ \\
\hline Gumbel & $\begin{array}{l}\mathrm{Cs}=1,14 \\
\mathrm{Ck}=5,4\end{array}$ \\
\hline Log Perason III & Other than the above values. \\
\hline
\end{tabular}


a. Sort the data from large to small and determine opportunities each data using the following formula:

$$
p=\frac{m}{n+1} \times 100 \%
$$

where: $\mathrm{P}$ is the probability (\%); $\mathrm{m}$ is the serial number of the data after sorted from large to small; and $\mathrm{n}$ is the number of years of data.

b. Determine the theoretical opportunities for each of these data by the distribution equation:

$$
\mathrm{P}^{\prime}=\frac{1}{T}
$$

c. From the value of these opportunities, determine the largest difference between the odds observations with theoretical opportunities:

$$
\mathrm{D}=\text { maksimum }\left[P\left(Q_{\text {maks }}\right)-P^{\prime}\left(Q_{\text {maks }}\right)\right]
$$

d. Based on Table 2, for the critical value of the Smirnov-Kolmogorov test determined the price Do.

e. If " $D$ " is smaller of "Do", then the distribution that used to determine the discharge plan is acceptable, otherwise if the price of $\mathrm{D}$ is greater of Do, then the distribution that used to determine the discharge plan is not accepted. Furthermore, determined discharge occurs according to Wesli [2008], there is rational formula made empirically that could explain the relationship between the rainfall runoff such as:

$$
Q=0,278 . C . I . A
$$

Where: $\mathrm{Q}$ is the discharge $(\mathrm{m} 3 / \mathrm{s})$; $\mathrm{C}$ is a flow coefficient; I is the intensity of rain during the time of concentration $(\mathrm{mm} / \mathrm{h})$ and $\mathrm{A}$ is the area of watershed $(\mathrm{km} 2)$

According to Soewarno [1995], discharge mainstay is a minimum flow rate of the river, which in certain opportunities can be used for water supply purposes such irrigation, drinking water,and electricity.

After discharge availability is obtained, it is necessary to count the discharge needs. According to Razuardi [2005], the need for water is an accumulation of water needs such as the need for water for domestic, livestock and rice fields. To determine the water needs can be used the following equation:

$$
\mathrm{Q}_{\mathrm{KA}}=\mathrm{Q}_{\mathrm{RT}}+\mathrm{Q}_{\mathrm{T}}+\mathrm{Q}_{\mathrm{T}}+\mathrm{Q}_{\mathrm{S}}+\mathrm{Q}_{\mathrm{P}} \ldots \ldots \ldots
$$

where: QKA is the need for water; QRT is a household water needs; QT is a need for livestock water; QS is the rice fields water requirement and QP is the water needs for fisheries.

The next step is to understand the characteristics of the reservoir reservoirs. According to
Susilah [2009], quoted of Linsey, RK, JB Franzini, D.L. Freyberg, and G. Tchobanoglous [1999], the most important characteristics of a reservoir is related to the ability of reservoirs to store water.

The policies for the operation of the storage capacity of reservoirs involves dividing into sections based on the planned function in the operation of the reservoir, distribution of storage capacity can be permanent or variable depending on the season or other factors. Bin consists of several zones, as shown in Figure-1.

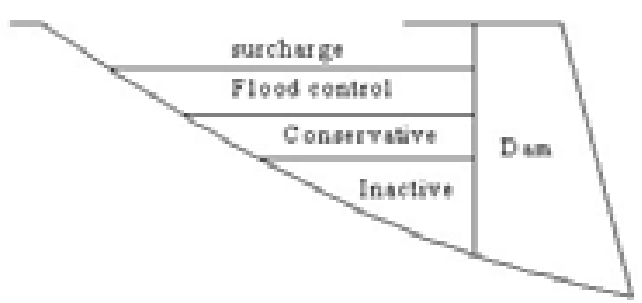

Figure 1. Reservoir zona

Reference: Susilah [2009]

According to Mays, Larry W. and Yeou Koung Tung [1992], the potential to accommodate a water reservoir (storage capacity) can be divided into three parts, namely:

Effective capacity (effective/usefull storage) is used to measure the capacity of conservation of water sources (such as raw water supply, irrigation, navigation, etc.), so that any use of the reservoir in the reservoir conservation can not exceed the capacity effectively.

Retaining capacity of the flood (flood control) is a useful reservoir capacity to hold excess water in order to reduce the potential for flood damage.

The pattern of reservoir operation must be known before the optimization model. According to Ibrahim [2003], the pattern of reservoir operation is operational benchmark a reservoir where water discharge issued by the reservoir must be in accordance with the provisions, so that the elevation maintained in accordance with the design.

Basic equation in simulated water balance in the reservoir is a function of the input, spending dams and reservoirs which can be presented in a simple equation:

$$
Q-O=d s / d t
$$

where: $\mathrm{I}$ is the input; $\mathrm{O}$ is the output and $\mathrm{Ds} / \mathrm{dt}=\Delta \mathrm{S}$ is the change in the pitcher.

Operating utilization of water resources is optimized very important aspect in the utilization of water resources, especially in reservoir operations planning. The principle of the method of optimization can be seen in Figure 2 . 
Table 2. Crisis value Do for Smirnov-Kolmogorov testing

\begin{tabular}{ccccc}
\hline $\mathrm{N}$ & \multicolumn{5}{c}{$\alpha$} \\
\cline { 2 - 5 } & 0,2 & 0,1 & 0,05 & 0,01 \\
\hline 5 & 0,45 & 0,51 & 0,56 & 0,67 \\
10 & 0,32 & 0,37 & 0,41 & 0,49 \\
15 & 0,27 & 0,3 & 0,34 & 0,4 \\
20 & 0,23 & 0,26 & 0,29 & 0,36 \\
25 & 0,21 & 0,24 & 0,27 & 0,32 \\
30 & 0,19 & 0,22 & 0,24 & 0,29 \\
35 & 0,18 & 0,2 & 0,23 & 0,27 \\
40 & 0,17 & 0,19 & 0,21 & 0,25 \\
45 & 0,16 & 0,18 & 0,2 & 0,24 \\
50 & 0,15 & 0,17 & 0,19 & 0,23 \\
$\mathrm{n}>50$ & $1,07 / \mathrm{n} 0,5$ & $1,22 / \mathrm{n} 0,5$ & $1,36 / \mathrm{n} 0,5$ & $1,63 / \mathrm{n} 0,5$ \\
\hline
\end{tabular}

Reference: Soewarno [1995]

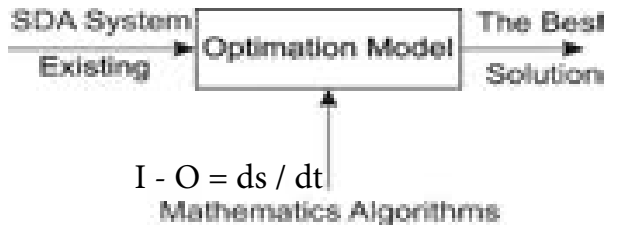

Figure 2 Optimation model scema

Reference: Ibrahim [2003]

Linear programming is one of the most popular optimization methods appliedin modeling reservoir systems optimization problems. It has been applied to variousreservoir systems problems with different aims, such as, determining optimal operat-ing policies [Heydari et al, 2015].

According to Aminudin [2005], linear programming (LP) is an analytical technique that is planning the analysis using a mathematical models, the goal is to find some combination of optimum alternative solutions to the problem. Linear programming problems involving many decision variables can be quickly solved with the help of a computer program package that is available as LINDO, QSB, TORA and others. Siswanto [2006] argued that linear programming is a mathematical method that is characterized by a linear to find an optimal solution in a way to maximize or minimize the objective function for the arrangement of obstacles.

Primary data is data observations taken directly in the field. In this study, the primary data is not required because the data used are already available in the institutions associated with the reservoir. Secondary data is data that is derived from a reference or from the appropriate agencies. Secondary data in this study include rainfall data, map location of reservoirs, watershed maps, reservoir inundation maps, evapotranspiration of data, the data area of rice fields, population data, the data area of livestock and fisheries, extensive data inundation, land use data, technical data streams, and reservoirs technical data, rainfall data are sourced from the Department of Agriculture province of Aceh. Monthly rainfall data is a form of precipitation data from 1996 through 2009. Rainfall data for 14 years was taken the smallest value or a minimum annually. Keuliling reservoir location map data, a map of the watershed Keuliling sourced from the Department of Water Resources of the Province. Keuliling reservoir inundation maps, evapotranspiration data is the data area of rice fields and reservoirs Keuliling was taken from Wiratman \& Associates consultant.

Population data, the data cattle, and the data area of fisheries sourced from the Central Statistics Agency (BPS) Banda Aceh. While extensive data inundation, land use data and technical data streams, and reservoirs Keuliling technical data are sourced from Wahana Adya consultant.

In preparing the reservoir operation pattern used optimization method. Completion of optimization problems using a linear program that begins with determining the decision variables are going to look for the optimum value of the variable. Then set up the objective function in the form of water storage reservoir volume each month. Then identified the constraints faced and functionally expressed in the form of equations or inequalities in the form of discharge of water availability and water discharge requirements.

- Objective Function:

$$
\operatorname{Max} V_{t}=V_{t+1}+V_{\dot{n}}-V_{\text {out }}
$$

- Constraints Function:

$V_{\text {in }}=V$ total inf low

$V_{\text {out }}=V$ total outlow

$V_{t-1}=V_{t-1}+V_{i}$ 
where: Vt is the volume of the dam reservoirs at the end of the month to $\mathrm{t}(\mathrm{m} 3)$; Vt-1 is the volume of reservoirs at the end of the previous month (m3); Vin is the inflow volume (m3) and Vout is the outflow volume (m3).

\section{Result and Discussion}

By using the Log Pearson III distribution, based on rainfall data can be obtained rain plan to return period of 5 years, 10 years, 20 years, 25 years and 50 years. For the five-year return period rainfall obtained plans for $41305 \mathrm{~mm}$, for the return period of 10 years was obtained for $53333 \mathrm{~mm}$, for a return period of 20 years was obtained for $58344 \mathrm{~mm}$, and for a return period of 25 years was obtained for 66834 $\mathrm{mm}$ and for the 50-year return period rainfall obtained plan of $75.683 \mathrm{~mm}$. More is shown in Table 3 .

From Table 3 above, can be made a graph that illustrates the rain plan as shown in Fig- ure 3. Figure 3 below shows that the greater the return period will greater the rain plan.

Based on the match test results of Smirnov-Kolmogorov distribution, indicates that the value of Dmax obtained for 0.437. Based on the 14 data and the degree of confidence of $\alpha=$ $8 \%$, it can be determined the value Do of 0.47 .

Based on the results of match tests, showed that the value of Dmax is smaller than the value Do. So distribution using Pearson Log III is acceptable.

Analysis of the availability of water is in the form of flow. For the 5-year return period was obtained for $57.345 \mathrm{~m} 3 / \mathrm{sec}$, for a period of 10 years obtained for $74.043 \mathrm{~m} 3 / \mathrm{sec}$, for a return period of 20 years was obtained for $81,000 \mathrm{~m} 3 / \mathrm{sec}$, for a return period of 25 years was obtained for $92.787 \mathrm{m3} / \mathrm{sec}$, and for 50 year return period was obtained for $105.072 \mathrm{~m} 3 / \mathrm{sec}$. While for the reliable discharge of the river is used,

Table 3. Calculation results rainy plan Log Pearson III distribution

\begin{tabular}{cccccc}
\hline Return Periode & $(\mathrm{mm})$ & $\mathrm{KT}_{\mathrm{T}}$ & $\mathrm{S}_{\mathrm{v}}$ & $\log \mathrm{Y}_{\mathrm{t}}$ & $(\mathrm{mm})$ \\
\hline 5 & 1,292 & 0,854 & 0,379 & 1,616 & 41,305 \\
10 & 1,292 & 1,147 & 0,379 & 1,727 & 53,333 \\
20 & 1,292 & 1,251 & 0,379 & 1,766 & 58,344 \\
25 & 1,292 & 1,407 & 0,379 & 1,825 & 66,834 \\
50 & 1,292 & 1,549 & 0,379 & 1,879 & 75,683 \\
\hline
\end{tabular}

Tabel 4. Discharge return period

\begin{tabular}{ccccc}
\hline $\begin{array}{c}\text { Tr } \\
(\text { Tahun })\end{array}$ & C & $\begin{array}{c}\mathrm{I} \\
(\mathrm{mm} / \mathrm{jam})\end{array}$ & $\begin{array}{c}\mathrm{A} \\
(\mathrm{km} 2)\end{array}$ & $\begin{array}{c}\mathrm{Q} \\
(\mathrm{m} 3 / \mathrm{det})\end{array}$ \\
\hline 5 & 0,75 & 7,200 & 38,2 & 57,345 \\
10 & 0,75 & 9,296 & 38,2 & 74,043 \\
20 & 0,75 & 10,170 & 38,2 & 81,000 \\
25 & 0,75 & 11,650 & 38,2 & 92,787 \\
50 & 0,75 & 13,192 & 38,2 & 105,072 \\
\hline
\end{tabular}

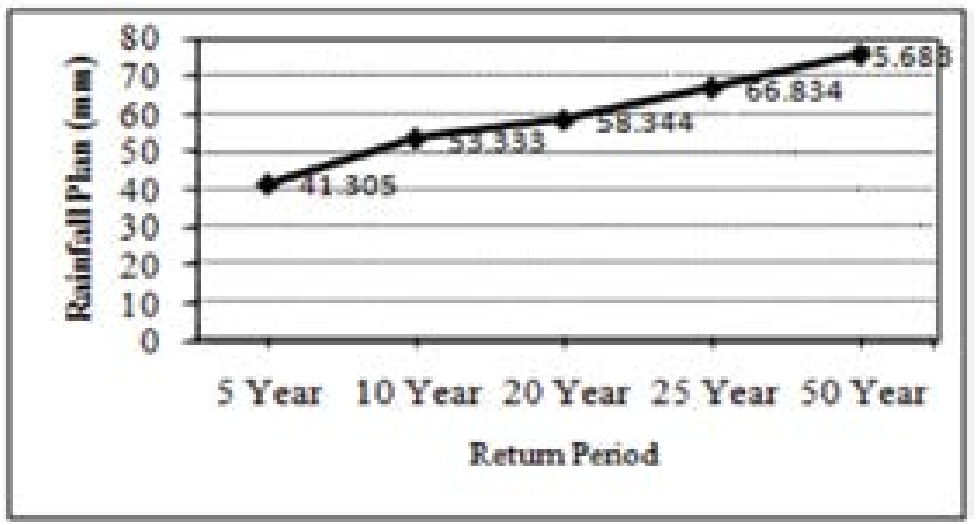

Figure 4. Discharge graphs of water availability and needs 
obtained from the data that already exists the amount of $1.240 \mathrm{~m} 3 / \mathrm{sec}$, more results are shown in Table 4 .

Water availability analysis is performed to determine the flow of water that would fill the reservoir. Water requirements analysis was conducted to determine the needs of the water as shown in Figure 4.

The figure illustrates that the discharge of water availability is greater than the water discharge requirements. It shows that the availability of water is able to meet the water needs. For optimization discharge water availability and water discharge requirements, use a minimum flow return period of 5 years.

Household water demand is obtained as follows: For the 5-year return period of $0,447 \mathrm{~m} 3 / \mathrm{sec}$, for a period of 10years of $0.468 \mathrm{~m} 3 / \mathrm{s}$, for a 20 -year return period of $0.511 \mathrm{~m} 3 / \mathrm{s}$, for a 25 -year return period of $0,532 \mathrm{~m} 3 / \mathrm{s}$, and for a period of 50 years anniversary of $0,639 \mathrm{~m} 3 / \mathrm{sec}$. To more clearly shown in Table 5

Table 5. The results of calculations of water demand for household.

\begin{tabular}{ccc}
\hline $\begin{array}{c}\mathrm{Tr} \\
(\text { Years })\end{array}$ & $\begin{array}{c}\hat{\mathrm{Y}} \\
\text { (person) }\end{array}$ & $\begin{array}{c}\text { QRT } \\
(\mathrm{m} 3 / \mathrm{det})\end{array}$ \\
\hline 5 & 321.782 & 0,447 \\
10 & 337.141 & 0,468 \\
20 & 367.857 & 0,511 \\
25 & 383.215 & 0,532 \\
50 & 460.006 & 0,639 \\
\hline
\end{tabular}

Table 6 . The results of calculations of water demand for Livestock.

\begin{tabular}{cc}
\hline Return Period & $\begin{array}{c}\text { Water demand } \\
(\mathrm{m} 3 / \text { det })\end{array}$ \\
\hline 5 & 0,087 \\
10 & 0,096 \\
20 & 0,126 \\
25 & 0,151 \\
50 & 0,859 \\
\hline
\end{tabular}

Water demand for livestock is as follows: For a period of 5 years anniversary of $0,087 \mathrm{~m} 3 / \mathrm{s}$, for a period of 10 years of $0.096 \mathrm{~m} 3 / \mathrm{s}$, for 20 -year return period of 0.126 $\mathrm{m} 3 / \mathrm{s}$, for the 25 -year return period of $0.151 \mathrm{~m} 3 / \mathrm{s}$, and for the 50 -year return period of $0.859 \mathrm{~m} 3 / \mathrm{sec}$. See Table 6 .

Based on calculations, the water requirement for paddy obtained for $100.436 \mathrm{~m} 3$ / s as shown in Table 7 .

Based on calculations, the water demands for fisheries is obtained as follows: For the 5-year return period of $0.23 \mathrm{~m} 3 / \mathrm{s}$, for 10years return period of $0.460 \mathrm{~m} 3 / \mathrm{s}$, for 20 -year return period of $0.920 \mathrm{~m} 3 / \mathrm{s}$, for the return period 25 years amounted to $1,150 \mathrm{~m} 3 / \mathrm{s}$, and for a return period of 50 years of $2,300 \mathrm{~m} 3 / \mathrm{sec}$. More can be seen in Table 8 .
The most of Water demand for the needs of agriculture (irrigation) where Rendeng season in April until June while the growing season gadu conducted in October to December. Based on the calculation of water, it can be recapitulated needs entirely every month by using the 5 year return period as shown in Table 9

Referring to the analysis of water availability based on the data series of rainfall for 15 years obtained the availability of water as shown in Table 4 and Figure 4 and recapitulation water needs every year as shown in Table 5-9 will be simulated the water balance of the supply and demand. From the simulation results illustrated the operation of the reservoir each month that the volume availability is eligible and there is excess water in the reservoir which illustrates that the capacity of the reservoir every month is sufficient as shown in Table 10

The optimization is done with the aim to optimize the volume of water storage dam each month. The optimization is translated into a mathematical equation proportionately on each discharge is limited by constraints in the form of constraint functions defined by discharge water demand and discharge water availability.

Table 6. The results of calculations of water demand for Livestock.

\begin{tabular}{cc}
\hline Return Period & $\begin{array}{c}\text { Water demand } \\
(\mathrm{m} 3 / \text { det })\end{array}$ \\
\hline 5 & 0,087 \\
10 & 0,096 \\
20 & 0,126 \\
25 & 0,151 \\
50 & 0,859 \\
\hline
\end{tabular}

Table 7. The results of calculations of water demand for Ricefield

\begin{tabular}{lccccc}
\hline Periode & & $\begin{array}{c}\text { Debit } \\
(\mathrm{m} 3 / \mathrm{s})\end{array}$ & Periode & $\begin{array}{c}\text { Debit } \\
(\mathrm{m} 3 / \mathrm{s})\end{array}$ \\
\hline October & 1 & 8.77 & April & 1 & 5.47 \\
& 2 & 8.77 & & 2 & 5.44 \\
November & 1 & 7.65 & May & 1 & 5.73 \\
& 2 & 3.19 & & 2 & 3.58 \\
December & 1 & 1.70 & June & 1 & 4.47 \\
& 2 & 2.53 & & 2 & 3.23 \\
January & 1 & 3.20 & July & 1 & 0 \\
& 2 & 2.23 & & 2 & 0 \\
February & 1 & 0.99 & August & 1 & 0 \\
& 2 & 9.83 & & 2 & 0 \\
Maret & 1 & 4.74 & Septem- & 1 & 0 \\
& & & ber & & \\
& 2 & 4.74 & & 2 & 0 \\
\hline
\end{tabular}


Tabel 8. The results of calculations of water demand for Fisheries

\begin{tabular}{ccc}
\hline $\begin{array}{c}\text { Tr } \\
\text { (Tahun) }\end{array}$ & $\begin{array}{c}\text { A(fp) } \\
\text { (ha) }\end{array}$ & $\begin{array}{c}\text { Qfp } \\
\text { (m3/det) }\end{array}$ \\
\hline 5 & 283,927 & 0,230 \\
10 & 567,854 & 0,460 \\
20 & $1.135,709$ & 0,920 \\
25 & $1.419,636$ & 1,150 \\
50 & $2.839,272$ & 2,300 \\
\hline
\end{tabular}

The Optimization carried out with Linear Programming models and using LINDO software. Based on the results of the optimization calculation values obtained water storage volume at the end of October is 37,115930 $\mathrm{m} 3$, at the end of November amounted to $91,678,820 \mathrm{~m} 3$, and at the end of January amounted to $44,589,300 \mathrm{~m} 3$.

\section{Conclusion}

Based on the results of dam operation optimization model, can be summarized as follows:

To optimize the operation of the dam, the input data in the form of a data flow (estimated from the data of rainfall), the reliability of the river dis- charge data, output data (in the form of water discharge data such as household water demand, water demand for livestock, to rice fields, and for fisheries).

Based on the results of the optimization operation of reservoir return period of 5 years, shows that the volume of water storage at the end of October was 37,115,930 $\mathrm{m} 3$, at the end of November amounted to $91,678,820 \mathrm{~m} 3$ and at the end of January amounted to $144,589,300 \mathrm{~m} 3$.

Based on the optimization calculations shown that from month to month never happened on the condition of the dead bin level, so the problem for all water demand can be resolved.

Based on the above results can be given conclusions and recommendations as follows: Besides the completion of a mathematical model using one of the software, it should also be compared with other software on the same case and the same model. It is aim that the results of the completion of the bias model closer to reality.

In line with the community regional development where the water needs of the year to continue is to increase Local Government expected to maintain water balance with sustainability environmentally the reservoir areas and strengthening of law enforcement against illegal logging so that water resources can be sustainable.

Table 9. Recapitulation of water demand

\begin{tabular}{cccccc}
\hline Month & $\begin{array}{c}\text { Households } \\
(\mathrm{m} 3 / \mathrm{det})\end{array}$ & $\begin{array}{c}\text { Ranch } \\
(\mathrm{m} 3 / \mathrm{det})\end{array}$ & $\begin{array}{c}\text { Rice Fields } \\
(\mathrm{m} 3 / \mathrm{det})\end{array}$ & $\begin{array}{c}\text { Fisheries } \\
(\mathrm{m} 3 / \mathrm{det})\end{array}$ & $\begin{array}{c}\text { Needs Total } \\
(\mathrm{m} 3 / \mathrm{det})\end{array}$ \\
\hline January & 0.447 & 0.087 & 5.430 & 0.230 & 6.19 \\
February & 0.447 & 0.087 & 10.820 & 0.230 & 11.58 \\
Maret & 0.447 & 0.087 & 9.470 & 0.230 & 10.23 \\
April & 0.447 & 0.087 & 10.910 & 0.230 & 11.67 \\
Mai & 0.447 & 0.087 & 9.310 & 0.230 & 10.07 \\
June & 0.447 & 0.087 & 7.700 & 0.230 & 8.46 \\
July & 0.447 & 0.087 & - & 0.230 & 0.76 \\
August & 0.447 & 0.087 & - & 0.230 & 0.76 \\
September & 0.447 & 0.087 & - & 0.230 & 0.76 \\
October & 0.447 & 0.087 & 17.550 & 0.230 & 18.31 \\
November & 0.447 & 0.087 & 10.840 & 0.230 & 11.60 \\
December & 0.447 & 0.087 & 4.240 & 0.230 & 5.00 \\
\hline
\end{tabular}




\section{References}

Aminudin

$$
\text { (2005), Principles }
$$

Operations Research, Erlangga, Jakarta. Anonymous (1986), Irrigation Planning Standards KP-01, Board of Public Works Publisher, Jakarta.

Anonymous (2009) Aceh

Besar in Figures, BPS Banda Aceh. Anonymous (2009), Profile Reservoir Keuliling Aceh Province, Wiratman \& Associates, Jakarta. Asdak Chay (1995), Hydrology and Watershed Management, Gadjah Mada University Press, Yogyakarta.

Hadihardaja. I.K. (2006), Reliability Analysis optimal operation of reservoir Kaskade Citarum to meet the needs of raw water, Design and Construction Journali. Vol. 5 No. 1.

Mohammad, H, Othman Faridah and Kourosh Qaderi (2015), Developing Optimal ReservoirOperation for Multiple and Multipurpose Reservoirs Using Mathematical Programming. Mathematical Problems in Engineering, Volume 2015. Article ID 435752. Ibrahim Agung, B. (2003), The Guidelines Operation Single Reservoir, Www. bintek-s p m.com/download/98.pdf.

Mays L.W., and Koung Tung, Yeow (1992), Hydro systems Engineering And Mangement, McGraw-Hill, New York.

Siswanto (2006), Operations Research, Jilid 1, Erlangga, Jakarta.. Soewarno (1995), Hydrology Measurement and Watershed Data Management (Hidrometri), Nova, Bandung. Srivastava, D,K, and Patel. I. A (1992), Optimization-simulation models for the design of an Irrigation project. Water Resources Management Volume 6, Issue 4, pp 315-338. Susilah (2009), Reservoir Operation Model System in Indonesia, Unimal Press, Lhokseumawe - Aceh.

Bambang, T (2009), Applied Hydrology, Beta Offset, Yogyakarta.

Tu, M. Y., Hsu, N. S., and Yeh, W. W. G. (2003), Optimization of reservoir management and operation with hedging rules. Journal of Water Resources Planning and Management. Wesli (2008), Urban Drainage, Graha Ilmu, Yogyakarta 